\title{
Is visceral adiposity a modifier for the impact of blood pressure on arterial stiffness and albuminuria in patients with type 2 diabetes?
}

Ryotaro Bouchi ${ }^{1 *}$, Norihiko Ohara', Masahiro Asakawa ${ }^{1}$, Yujiro Nakano ${ }^{1}$, Takato Takeuchi ${ }^{1}$, Masanori Murakami ${ }^{1}$, Yuriko Sasahara', Mitsuyuki Numasawa', Isao Minami', Hajime Izumiyama1,2, Koshi Hashimoto 1,3, Takanobu Yoshimoto ${ }^{1}$ and Yoshihiro Ogawa ${ }^{1,4}$

\begin{abstract}
Background: We aimed to investigate whether visceral adiposity could modify the impact of blood pressure on arterial stiffness and albuminuria in patients with type 2 diabetes.

Methods: This cross-sectional study examines the interaction of visceral adiposity with increased blood pressure on arterial stiffness and albuminuria. 638 patients with type 2 diabetes (mean age $64 \pm 12$ years; $40 \%$ female) were enrolled. Visceral fat area (VFA, $\mathrm{cm}^{2}$ ) was assessed by a dual-impedance analyzer, whereby patients were divided into those with VFA $<100(N=341)$ and those with VFA $\geq 100(N=297)$. Albuminuria was measured in a single 24-h urine collection (UAE, mg/day) and brachial-ankle pulse wave velocity (ba-PWV, cm/s) was used for the assessment of arterial stiffening. Linear regression analyses were used to investigate the association of systolic blood pressure (SBP) and VFA with UAE and baPWV.
\end{abstract}

Results: Patients with VFA $\geq 100$ were significantly younger, had higher SBP, HbA1c, triglycerides, UAE, alanine aminotransferase, C-reactive protein and lower high-density lipoprotein and shorter duration of diabetes than those with VFA $<100$. SBP was significantly and almost equivalently associated with ba-PWV both in VFA $<100$ (standardized $\beta 0.224, p=0.001$ ) and VFA $\geq 100$ (standardized $\beta 0.196, p=0.004$ ) patients in the multivariate regression analysis adjusting for covariates including age, gender, $\mathrm{HbA1c}$, diabetic complications and the use of insulin and anti-hypertensive agents. By contrast, the association of SBP with UAE was stronger in patients with VFA $\geq 100$ (standardized $\beta$ $0.263, p=0.001$ ) than that in patients with VFA $<100$ (standardized $\beta 0.140, p=0.080$ ) in the multivariate regression model. In the whole cohort, the significant interaction between SBP and VFA on UAE (standardized $\beta 0.172, p=0.040$ ) but not on ba-PWV (standardized $\beta-0.008, p=0.916$ ) was observed.

Conclusions: The effect of increased blood pressure on arterial stiffness is almost similar in type 2 diabetic patients with both low and high visceral adiposity, while its association with albuminuria is stronger in the latter.

Keywords: Visceral adiposity, Blood pressure, Arterial stiffness, Albuminuria, Type 2 diabetes

\footnotetext{
*Correspondence: bouchi.mem@tmd.ac.jp

${ }^{1}$ Department of Molecular Endocrinology and Metabolism, Graduate

School of Medical and Dental Sciences, Tokyo Medical and Dental

University, 1-5-45 Yushima, Bunkyo-ku, Tokyo 113-8510, Japan

Full list of author information is available at the end of the article
} 


\section{Background}

Blood pressure is a strong risk factor for cardiovascular disease (CVD) [1, 2] and chronic kidney disease (CKD) [3-5]. Among patients with diabetes, hypertension is associated with the incidence of CVD and CKD as well [6-9]. The reduction of blood pressure could reduce the risks both for CVD and CKD.

Obesity, especially increased visceral adiposity is a major cause of hypertension, accounting for $65-75 \%$ of the risk for human essential hypertension [10]. In addition, obesity has been reported to be associated with various cardio-metabolic risks including insulin resistance and dyslipidemia, and also be directly associated with CVD [11-14]. Furthermore, abdominal obesity is a strong risk factor for CKD both in general population and patients with diabetes $[15,16]$. Therefore, abdominal adiposity is thought to be an important determinant that can account for the association of cardio-metabolic risks with CVD and CKD.

Regarding the association between blood pressure and CVD, the impact of elevated blood pressure on CVD events has been reported to be stronger among people without obesity than those with [17-19]. Also, it has been suggested that normal-weight patients with essential hypertension have increased arterial stiffness [20] and systemic vascular resistance. We recently reported that increased visceral adiposity with normal weight is strongly associated with cardio-metabolic risks and arterial stiffness in patients with type 2 diabetes [21]. These studies imply that visceral adiposity could modify the impact of blood pressure on CVD; however, it is uncertain whether increased blood pressure could more strongly affect arterial stiffening in people with low visceral adiposity than in those with high visceral adiposity. On the other hand, among obese people, especially those with high visceral adiposity, intra-renal renin-angiotensinaldosterone system is activated [22-24], leading to the glomerular hyperfiltration at the early stage of obesity-hypertension. Hyperglycemia also induces renal damage directly or through hemodynamic modifications including glomerular hyperfiltration [25]. Therefore, it is possible that increase in systemic blood pressure could more strongly affect the renal hemodynamics in obese, especially in obese patients with diabetes, than in non-obese people, resulting in more severe renal manifestations such as increased albuminuria and decreased glomerular filtration rate (GFR). Taken together, we conducted this cross-sectional study to investigate the interaction of visceral adiposity with blood pressure on the increased risk for arterial stiffening and albuminuria in patients with type 2 diabetes.

\section{Methods \\ Subjects}

Patients with type 2 diabetes who admitted to Tokyo Medical and Dental University Hospital for the purpose of glycemic control and/or evaluation of diabetic complications participated in this cross-sectional study. Patients were eligible, if they were aged $\geq 20$ years, and patients who measured both brachia-ankle pulse wave velocity (ba-PWV) and visceral fat area (VFA) and subcutaneous fat area (SFA) by a dual bioelectrical impedance analyzer were enrolled. Patients with severe renal impairment (estimated glomerular filtration rate [eGFR] $<15 \mathrm{~mL} /$ $\mathrm{min} / 1.73 \mathrm{~m}^{2}$ or undergoing renal replacement therapy), pregnant women, and those with infectious or malignant diseases were excluded. Type 2 diabetes was diagnosed according to the criteria of the Japan Diabetes Society (JDS) [26]. As shown in Fig. 1, 638 patients were finally enrolled in this study. This study complies with the principles laid by Declaration of Helsinki and has been approved by the ethical committee of Tokyo Medical and Dental University (No. 1924).

\section{Clinical and biochemical analysis}

Standardized questionnaires were used to obtain information on smoking, medication and past history. Smoking history was classified as either current smoker or non-smoker. CVD was defined as the presence of a previous stroke, myocardial infarction, coronary revascularization procedure. Blood pressure was measured in the sitting position after at least 5 min rest, using an electronic sphygmomanometer (ES-H55, Terumo Inc.,

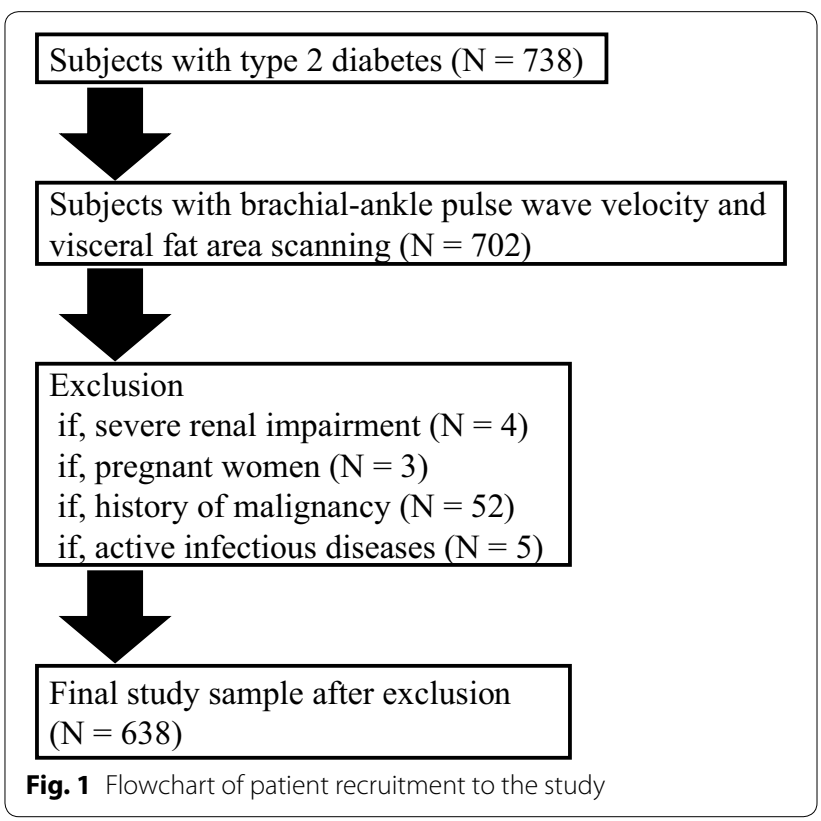


Tokyo, Japan). HbA1c was measured by the latex agglutination method. HbA1c levels were expressed in accordance with the National Glycohemoglobin Standardization Programs recommended by the Japanese Diabetes Society [26]. Urinary albumin (UAE) and creatinine excretion were measured by the turbidimetric immunoassay and enzymatic method, respectively, in a single 24 -h urine collection. GFR was estimated using the following equation for the Japanese, as proposed by the Japanese Society of Nephrology [27]; GFR $=194 \times \mathrm{SCr}^{-1.094} \times \mathrm{age}^{-0.287}$ [(if female) $\times 0.739$ ], where SCr stands for serum creatinine in $\mathrm{mg} / \mathrm{dl}$, measured by an enzymatic method. Coefficient of variation of $R-R$ intervals (CV-RR) was used for the assessment of diabetic neuropathy. BMI was calculated as weight divided by the square of height $(\mathrm{kg} /$ $\mathrm{m}^{2}$ ). VFA and SFA were measured at the level of umbilicus by dual bioelectrical impedance analyzer (DUALSCAN, Omron Healthcare Co., Kyoto, Japan). Patients were divided into those with VFA $<100 \mathrm{~cm}^{2}$ (low-V) and those with VFA $\geq 100 \mathrm{~cm}^{2}$ (high-V). Brachial-ankle pulse wave velocity (ba-PWV) was measured using a volumeplethysmographic apparatus (BP-203RPE II form PWV/ ABI, Omron Healthcare Co., Kyoto, Japan), with subjects in the supine position after at least 5 min of rest $[28,29]$. The ba-PWV was calculated as reported previously [30]. We simultaneously measured ba-PWV on both the right and left sides and the averaged values from each individual were subjected to statistical analysis.

\section{Statistical analysis}

Statistical analysis was performed using programs available in the SPSS version 21.0 statistical package (SPSS Inc., Chicago, IL, USA). Data are presented as mean $\pm \mathrm{SD}$, median with interquartile range (IQR), or percent as appropriate according to data distribution. Normality was tested by the Kolmogorov-Smirnov test. Differences between low- $\mathrm{V}$ and high- $\mathrm{V}$ patients were tested with a $t$ test or Mann-Whitney $\mathrm{U}$ test for continuous variables and Chi square test for categorical variables. Linear regression analyses were used to investigate the association of SBP and VFA with ba-PWV and UAE. We determined the linear relationship and multicollinearity for regression assumptions. We removed one variable if a strong correlation (coefficient of correlation $>0.8$ ) was observed between the two independent variables. In order to check the multicollinearity, we evaluated variance infiltration factors. If multicollinearity was found in the data, one variable was removed from the multivariate regression analysis. The following covariates were incorporated into the analysis with a stepwise procedure; duration of diabetes, smoking status, triglycerides, highdensity lipoprotein (HDL) cholesterol, low-density lipoprotein (LDL) cholesterol, HbA1c, eGFR, log CRP and the usage of insulin, calcium channel blockers (CCB), angiotensin receptor blockers (ARB), statins and antiplatelet agents. Age and gender were forced into the model. The interaction between SBP and VFA was also investigated in the multiple linear regression analyses. Differences were considered to be statistically significant at $\mathrm{p}$ value less than 0.05 .

\section{Results}

\section{Clinical characteristics of patients with low-V and high-V}

Among 638 patients, 341 and 297 were classified as low-V and high- $\mathrm{V}$ patients. As shown in Table 1 , high- $\mathrm{V}$ patients were significantly younger, had significantly higher SBP and DBP, lower HDL-C, higher triglycerides levels and a shorter duration of diabetes than the low- $V$ patients. Urinary C-peptide and UAE levels in high-V patients were significantly higher than those in low- $\mathrm{V}$ patients. BMI, WC, VFA and SFA levels in high-V patients were significantly higher than in those with low-V. The high$\mathrm{V}$ patients were more frequently receiving $\mathrm{CCBs}$, ARBs and statin therapy and were less likely to receive insulin than low-V patients. baPWV in high-V patients was significantly lower than that in low- $\mathrm{V}$ patients.

\section{Association between SBP and baPWV according to VFA categories}

Table 2 shows the linear regression analyses to investigate the association between SBP and ba-PWV in patients with low-V and those with high- $\mathrm{V}$. In the univariate model, SBP was significantly and equivalently associated with ba-PWV. After adjusting for age and gender, the statistical significance of SBP with ba-PWV was unchanged both in patients with low-V and those with high-V. In the multivariate model including covariates such as eGFR and anti-hypertensive agents, the association of SBP with ba-PWV remained significant regardless of visceral adiposity (standardized $\beta 0.224, \mathrm{p}=0.001$ in low- $\mathrm{V}$ and standardized $\beta$ 0.196, $p=0.004$ in high-V). Among patients with high-V, SFA was inversely associated with ba-PWV (standardized $\beta-0.199, \mathrm{p}=0.007$ ). eGFR was a significant covariate regardless of visceral adiposity.

\section{Association between SBP and UAE according to VFA categories}

Table 3 shows the association between SBP and UAE according to VFA categories among patients with type 2 diabetes. In the univariate model, SBP was significantly associated with UAE both in patients with low-V and those with high-V. The association of SBP with UAE was unchanged in age- and gender-adjusted model regardless of visceral adiposity (standardized $\beta 0.205, \mathrm{p}=0.001$ in patients with low-V and standardized $\beta 0.290, \mathrm{p}<0.001$ in patients with high-V). In the multivariate model 
Table 1 Clinical characteristics according to VFA levels

\begin{tabular}{|c|c|c|c|}
\hline & VFA $<100 \mathrm{~cm}^{2}(\mathrm{~N}=341)$ & VFA $\geq 100 \mathrm{~cm}^{2}(\mathrm{~N}=297)$ & p values \\
\hline Age (years) & $66 \pm 12$ & $62 \pm 13$ & $<0.001$ \\
\hline Gender (\% male) & 57 & 63 & 0.196 \\
\hline $\mathrm{SBP}(\mathrm{mmHg})$ & $128 \pm 20$ & $132 \pm 17$ & 0.016 \\
\hline $\mathrm{DBP}(\mathrm{mmHg})$ & $73 \pm 12$ & $78 \pm 12$ & $<0.001$ \\
\hline $\mathrm{HbA1c}(\mathrm{mmol} / \mathrm{mol})$ & $71.6 \pm 20.2$ & $75.0 \pm 19.5$ & 0.029 \\
\hline $\mathrm{HbA1c}(\%)$ & $8.7 \pm 1.8$ & $9.0 \pm 1.8$ & \\
\hline HDL-cholesterol (mmol/l) & $1.32 \pm 0.42$ & $1.19 \pm 0.31$ & $<0.001$ \\
\hline LDL-cholesterol (mmol/l) & $2.87(2.29-3.56)$ & $2.79(2.26-3.44)$ & 0.515 \\
\hline Triglycerides (mmol/l) & $1.31(0.98-1.86)$ & $1.61(1.19-2.26)$ & $<0.001$ \\
\hline Urinary C-peptide ( $\mu \mathrm{g} /$ day) & $42(27-67)$ & $60(35-99)$ & $<0.001$ \\
\hline Duration of diabetes (years) & $12(5-20)$ & $10(4-16)$ & 0.044 \\
\hline Current smoker (\%) & 22 & 25 & 0.452 \\
\hline History of CVD & 13 & 17 & 0.183 \\
\hline UAE (mg/day) & $11(7-26)$ & $19(10-58)$ & 0.001 \\
\hline $\operatorname{eGFR}\left(\mathrm{ml} / \mathrm{min} / 1.73 \mathrm{~m}^{2}\right)$ & $72.0 \pm 23.3$ & $71.5 \pm 25.6$ & 0.791 \\
\hline AST (U/I) & $22(17-28)$ & $24(19-41)$ & $<0.001$ \\
\hline $\operatorname{ALT}(U / I)$ & $19(14-30)$ & $28(18-48)$ & $<0.001$ \\
\hline C-reactive protein (mg/l) & $0.80(0.40-1.95)$ & $1.60(0.80-3.60)$ & $<0.001$ \\
\hline PDR (\%) & 19 & 12 & 0.536 \\
\hline CV-RR (\%) & $3.3(2.2-4.8)$ & $3.6(2.3-5.3)$ & 0.109 \\
\hline ba-PWV (cm/s) & $1711(1459-1906)$ & $1582(1411-1785)$ & 0.007 \\
\hline Body mass index $\left(\mathrm{kg} / \mathrm{m}^{2}\right)$ & $23.5 \pm 3.2$ & $29.4 \pm 4.4$ & $<0.001$ \\
\hline Waist circumference (cm) & $86 \pm 9$ & $102 \pm 11$ & $<0.001$ \\
\hline Visceral fat area $\left(\mathrm{cm}^{2}\right)$ & $74(57-87)$ & $133(114-152)$ & $<0.001$ \\
\hline Subcutaneous fat area $\left(\mathrm{cm}^{2}\right)$ & $144(120-178)$ & $236(194-284)$ & $<0.001$ \\
\hline Insulin (\%) & 75 & 61 & 0.002 \\
\hline CCBs (\%) & 29 & 39 & 0.023 \\
\hline ARBs (\%) & 35 & 53 & $<0.001$ \\
\hline Statin (\%) & 42 & 52 & 0.050 \\
\hline Anti-platelets (\%) & 17 & 22 & 0.322 \\
\hline
\end{tabular}

$A L T$ alanine aminotransferase, $A R B$ angiotensin receptor blocker, $A S T$ asparatate aminotransferase, baPWV brachial-ankle pulse wave velocity, $C C B$ calcium channel blocker, CVD cardiovascular disease, CV-RR coefficient of variation of R-R intervals, DBP diastolic blood pressure, eGFR estimated glomerular filtration rate, $H D L$ highdensity lipoprotein, $L D L$ low-density lipoprotein, $P D R$ proliferative diabetic retinopathy, $S B P$ systolic blood pressure

adjusting for covariates including age, gender, diabetic complications such as neuropathy and retinopathy and HbA1c level, SBP remained significantly associated with UAE in patients with high-V (standardized $\beta$ 0.263, $\mathrm{p}=0.001$ ); whereas, its association with UAE was attenuated in those patients with low-V (standardized $\beta 0.140$, $\mathrm{p}=0.080)$.

\section{Interaction between SBP and VFA accounting for the risk of arterial stiffening and albuminuria}

Table 4 shows the multivariate linear regression analyses to investigate whether binary interaction between SBP and VFA could account for the risks of arterial stiffening and albuminuria in the whole cohort. The significant interaction between SBP and VFA was observed in the model where UAE was used for a dependent variable; whereas, no significant interaction of SBP with VFA was found as for ba-PWV.

\section{Discussion}

Both increased arterial stiffness and albuminuria are strong predictors for mortality, CVD and CKD in patients with diabetes [31-36]. Therefore, it is important to elucidate the high risk groups both for increased arterial stiffness and albuminuria among diabetic patients. This study clearly demonstrates that increased SBP can equivalently account for the risk for arterial stiffening regardless of visceral adiposity; whereas, the impact of SBP on albuminuria is stronger in diabetic patients with high visceral adiposity than those with low visceral adiposity. 
Table 2 Linear regression analysis to investigate the association of blood pressure and visceral adiposity with arterial stiffness in patients with type 2 diabetes

\begin{tabular}{|c|c|c|c|c|}
\hline & \multicolumn{2}{|c|}{ VFA $<100 \mathrm{~cm}^{2}$} & \multicolumn{2}{|c|}{$V F A \geq 100 \mathrm{~cm}^{2}$} \\
\hline & $\begin{array}{l}\text { Standard- } \\
\text { ized } \beta\end{array}$ & $p$ values & $\begin{array}{l}\text { Standard- } \\
\text { ized } \beta\end{array}$ & $p$ values \\
\hline \multicolumn{5}{|l|}{ Univariate } \\
\hline $\begin{array}{l}\text { Systolic blood } \\
\text { pressure }\end{array}$ & 0.183 & 0.001 & 0.215 & \\
\hline \multicolumn{5}{|c|}{ Age- and gender-adjusted } \\
\hline $\begin{array}{l}\text { Systolic blood } \\
\text { pressure }\end{array}$ & 0.172 & 0.001 & 0.253 & \\
\hline Age & 0.426 & $<0.001$ & 0.421 & \\
\hline $\begin{array}{l}\text { Gender (male } \\
\text { versus female) }\end{array}$ & 0.071 & 0.151 & 0.044 & \\
\hline \multicolumn{5}{|l|}{ Multivariate } \\
\hline $\begin{array}{l}\text { Systolic blood } \\
\text { pressure }\end{array}$ & 0.224 & 0.001 & 0.196 & 0.004 \\
\hline Age & 0.430 & $<0.001$ & 0.383 & $<0.001$ \\
\hline $\begin{array}{l}\text { Gender (male } \\
\text { versus female) }\end{array}$ & 0.130 & 0.051 & 0.007 & 0.920 \\
\hline eGFR & -0.087 & 0.055 & -0.199 & 0.042 \\
\hline SFA & NA & & 0.149 & 0.007 \\
\hline CCB & NA & & -0.155 & 0.031 \\
\hline
\end{tabular}

CCB calcium channel blocker, eGFR estimated glomerular filtration rate, SFA subcutaneous fat area, VFA visceral fat area

\section{Association of blood pressure and visceral adiposity with organ damage}

Visceral adiposity has been reported to be associated with incident hypertension [37, 38] and albuminuria $[39,40]$. More recently, we found that high visceral fat with low subcutaneous fat accumulation is an important determinant of carotid atherosclerosis and high subcutaneous fat could be protective against atherosclerosis in patients with type 2 diabetes [41], and others reported that subcutaneous fat thickness assessed by ultrasound is inversely associated with carotid atherosclerosis in diabetic patients, particularly in men [42]. Moreover, visceral adiposity is strongly associated with the alteration of myocardial glucose uptake and its association further relates to type 2 diabetes [43]. These studies suggest that visceral and subcutaneous adiposities are directly associated not only cardio-metabolic risks but also target organ damage including heart and arterial wall injuries. We found in this study a stronger association of blood pressure with albuminuria in patients with high visceral adiposity than those with low visceral adiposity, suggesting that visceral adiposity could modify the association of blood pressure at least with albuminuria in patients with type 2 diabetes.
Table 3 Linear regression analysis to investigate the association of blood pressure and visceral adiposity with albuminuria in patients with type 2 diabetes

\begin{tabular}{|c|c|c|c|c|}
\hline & \multicolumn{2}{|c|}{ VFA $<100 \mathrm{~cm}^{2}$} & \multicolumn{2}{|c|}{ VFA $\geq 100 \mathrm{~cm}^{2}$} \\
\hline & $\begin{array}{l}\text { Standard- } \\
\text { ized } \beta\end{array}$ & $p$ values & $\begin{array}{l}\text { Standard- } \\
\text { ized } \beta\end{array}$ & $p$ values \\
\hline \multicolumn{5}{|l|}{ Univariate } \\
\hline $\begin{array}{l}\text { Systolic blood } \\
\text { pressure }\end{array}$ & 0.203 & 0.001 & 0.280 & $<0.001$ \\
\hline \multicolumn{5}{|c|}{ Age- and gender-adjusted } \\
\hline $\begin{array}{l}\text { Systolic blood } \\
\text { pressure }\end{array}$ & 0.205 & 0.001 & 0.290 & $<0.001$ \\
\hline Age & 0.079 & 0.188 & 0.172 & 0.172 \\
\hline $\begin{array}{l}\text { Gender (male } \\
\text { versus female) }\end{array}$ & 0.074 & 0.219 & 0.087 & 0.087 \\
\hline \multicolumn{5}{|l|}{ Multivariate } \\
\hline $\begin{array}{l}\text { Systolic blood } \\
\text { pressure }\end{array}$ & 0.140 & 0.080 & 0.263 & 0.001 \\
\hline Age & -0.042 & 0.649 & -0.090 & 0.236 \\
\hline $\begin{array}{l}\text { Gender (male } \\
\text { versus female) }\end{array}$ & 0.120 & 0.122 & 0.166 & 0.28 \\
\hline eGFR & -0.191 & 0.042 & NA & \\
\hline Insulin & 0.145 & 0.064 & NA & \\
\hline PDR & 0.172 & 0.024 & NA & \\
\hline CV-RR & -0.142 & 0.075 & -0.161 & 0.034 \\
\hline $\mathrm{HbA} 1 \mathrm{c}$ & & & 0.135 & 0.076 \\
\hline
\end{tabular}

CV-RR Coefficient of variation of RR intervals, eGFR estimated glomerular filtration rate, $P D R$ proliferative diabetic retinopathy, VFA visceral fat area

Potential mechanisms regarding the interaction between blood pressure and adiposity on albuminuria

By which mechanisms are involved in the greater impact of elevated blood pressure on albuminuria in patients with high visceral adiposity than in those with low visceral adiposity? Sympathetic activity and local (renal) renin-angiotensin-aldosterone system could account for the association. Obesity increases sympathetic activity in the kidneys and skeletal muscle; however, cardiac sympathetic activity may not be elevated [44-46]. Furthermore, excessive weight gain, especially visceral adiposity increases leptin level, promotes renal compression, activates renal renin-angiotensin-aldosterone system [47], all of which could impair renal-pressure natriuresis, increase glomerular pressure, leading to progression of albuminuria. These observations could at least partly explain why elevated blood pressure is more strongly associated with albuminuria among patients with high visceral adiposity than among patients with low visceral adiposity.

\section{Strengths and limitations}

The strength of our study is that we directly measured VFA by a dual-impedance analyzer for the assessment 
Table 4 Interaction between blood pressure and visceral adiposity accounting for the risk of arterial stiffening and albuminuria in patients with type 2 diabetes

\begin{tabular}{|c|c|c|c|c|}
\hline & \multicolumn{2}{|l|}{ ba-PWV } & \multicolumn{2}{|l|}{ UAE } \\
\hline & $\begin{array}{l}\text { Standard- } \\
\text { ized } \beta\end{array}$ & $p$ values & $\begin{array}{l}\text { Standard- } \\
\text { ized } \beta\end{array}$ & $p$ values \\
\hline$S B P \times V F A$ & -0.008 & 0.916 & 0.172 & 0.040 \\
\hline $\begin{array}{l}\text { Systolic blood } \\
\text { pressure }\end{array}$ & 0.177 & $<0.001$ & 0.171 & 0.001 \\
\hline Visceral fat area & 0.149 & 0.149 & -0.060 & 0.471 \\
\hline Age & 0.430 & $<0.001$ & NA & \\
\hline $\begin{array}{l}\text { Body mass } \\
\text { index }\end{array}$ & -0.299 & 0.001 & NA & \\
\hline eGFR & -0.146 & 0.008 & NA & \\
\hline $\begin{array}{c}\text { Calcium chan- } \\
\text { nel blocker }\end{array}$ & 0.109 & 0.029 & NA & \\
\hline $\mathrm{HbA} 1 \mathrm{c}$ & NA & & -0.138 & 0.009 \\
\hline CV-RR & NA & & 0.148 & 0.005 \\
\hline $\begin{array}{l}\text { Gender (male } \\
\text { versus } \\
\text { female) }\end{array}$ & NA & & 0.130 & 0.015 \\
\hline $\begin{array}{l}\text { Angiotensin } \\
\text { receptor } \\
\text { blocker }\end{array}$ & NA & & 0.114 & 0.030 \\
\hline Insulin & NA & & 0.109 & 0.035 \\
\hline
\end{tabular}

ba-PWV brachial-ankle pulse wave velocity, CV-RR Coefficient of variation of RR intervals, eGFR estimated glomerular filtration rate, SBP systolic blood pressure, UAE urinary albumin excretion, VFA visceral fat area

of visceral adiposity. Previous studies assessed the interaction of adiposity with the association between hypertension and CVD using BMI or WC [7, 8, 48]. Thus, to the best our knowledge, this study is the first to investigate the interaction of visceral adiposity directly measured and blood pressure both with arterial stiffness and albuminuria. This study has a couple of limitations that should be mentioned. First, it has recently been reported that absolute loss of visceral fat mass may play a major role in resolution of diabetes following bariatric surgery, regardless of the amount of weight loss [49], suggesting the importance of prospectively evaluating the change in visceral adiposity to investigate the association between cardio-metabolic risks including blood pressure and organ damage such as arterial stiffening and albuminuria; however, it is impossible to infer causality because of its cross-sectional design. Second, population in this study was ethnically and socially homogeneous, because this study was hospital-based; therefore, generalization of our findings might be limited. Third, we were unable to obtain information on renin-angiotensin-aldosterone system and sympathetic activity. Fourth, we were unable to obtain any information on diet including vitamin A which may reduce visceral fat [50]. Finally, it is to be elucidated whether the association of blood pressure with arterial stiffness and albuminuria could be mediated by visceral adiposity in populations other than diabetic patients.

\section{Conclusion}

The effect of increased blood pressure on arterial stiffness is almost similar in type 2 diabetic patients with both low and high visceral adiposity, while its association with albuminuria is stronger in the latter.

\section{Abbreviations \\ ALT: Alanine Aminotransferase; ARB: angiotensin receptor blocker; AST: Asparatate Aminotransferase; baPWV: brachial-ankle pulse wave velocity; CCB: calcium channel blocker; Cl: confidence interval; CRP: C-reactive protein; CVD: cardiovascular disease; CV-RR: coefficient of variation of R-R intervals; eGFR: estimated glomerular filtration rate; HDL: high-density lipoprotein; LDL: low- density lipoprotein; PDR: proliferative diabetic retinopathy; SFA: subcutaneous fat area; UAE: urinary albumin excretion; VFA: visceral fat area.}

\section{Authors' contributions}

All authors have made substantial contributions to this study. RB designed the study, researched data, and wrote and edited the manuscript. RB, IM, TY, and $\mathrm{YO}$ contributed to intellectual discussion and reviewed and edited the manuscript. MN, YS, MA, TT, MM, YN, NO, HI and $\mathrm{KH}$ researched data. As the corresponding author and guarantor of this manuscript, $\mathrm{RB}$ is the guarantor of this work and, as such, had full access to all the data in the study and takes responsibility for the integrity of the data and the accuracy of the data analysis. All authors read and approved the final manuscript.

\section{Author details}

1 Department of Molecular Endocrinology and Metabolism, Graduate School of Medical and Dental Sciences, Tokyo Medical and Dental University, 1-5-45 Yushima, Bunkyo-ku, Tokyo 113-8510, Japan. ${ }^{2}$ Center for Medical Welfare and Liaison Services, Tokyo Medical and Dental University, Tokyo, Japan. ${ }^{3}$ Department of Preemptive Medicine and Metabolism, Graduate School of Medical and Dental Sciences, Tokyo Medical and Dental University, Tokyo, Japan. ${ }^{4}$ CREST, Japan Agency for Medical Research and Development, Tokyo, Japan

\section{Acknowledgements}

This study was supported by grants-in-aid from the Ministry of Health, Labor, and Welfare of Japan (Comprehensive Research on Lifestyle-Related Diseases Including Cardiovascular Diseases and Diabetes Mellitus).

\section{Competing interests}

The authors declare that they have no competing interests.

Received: 25 November 2015 Accepted: 13 January 2016

Published online: 21 January 2016

\section{References}

1. Fujiyoshi A, Ohkubo T, Miura K, Murakami Y, Nagasawa SY, Okamura T, Ueshima H, Observational Cohorts in Japan (EPOCH-JAPAN) Research Group. Blood pressure categories and long-term risk of cardiovascular disease according to age group in Japanese men and women. Hypertens Res. 2012;35:947-53.

2. Ikeda A, Iso H, Yamagishi K, Inoue M, Tsugane S. Blood pressure and the risk of stroke, cardiovascular disease, and all-cause mortality among Japanese: the JPHC Study. Am J Hypertens. 2009;22:273-80.

3. Fukuhara M, Arima H, Ninomiya T, Hata J, Yonemoto K, Doi Y, Hirakawa Y, Matsumura K, Kitazono T, Kiyohara Y. Impact of lower range of prehypertension on cardiovascular events in a general population: the Hisayama Study. J Hypertens. 2012;30:893-900.

4. Tozawa M, Iseki K, Iseki C, Kinjo K, Ikemiya Y, Takishita S. Blood pressure predicts risk of developing end-stage renal disease in men and women. Hypertension. 2003;41:1341-5. 
5. Yamagata K, Ishida K, Sairenchi T, Takahashi H, Ohba S, Shiigai T, Narita M, Koyama A. Risk factors for chronic kidney disease in a community-based population: a 10-year follow-up study. Kidney Int. 2007;71:159-66.

6. Kanno A, Kikuya M, Ohkubo T, Hashimoto T, Satoh M, Hirose T, Obara T, Metoki H, Inoue R, Asayama K, et al. Pre-hypertension as a significant predictor of chronic kidney disease in a general population: the Ohasama Study. Nephrol Dial Transplant. 2012;27:3218-23.

7. Fuller JH, Stevens LK, Wang SL. Risk factors for cardiovascular mortality and morbidity: the WHO mutinational study of vascular disease in diabetes. Diabetologia. 2001;44(Suppl 2):S54-64

8. Ritz E, Orth SR. Nephropathy in patients with type 2 diabetes mellitus. N Engl J Med. 1999;341:1127-33.

9. Molitch ME, Adler Al, Flyvbjerg A, Nelson RG, So WY, Wanner C, Kasiske BL, Wheeler DC, de Zeeuw D, Mogensen CE. Diabetic kidney disease: a clinical update from kidney disease: improving global outcomes. Kidney Int. 2015;87:20-30.

10. Garrison RJ, Kannel WB, Stokes J 3rd, Castelli WP. Incidence and precursors of hypertension in young adults: the Framingham Offspring Study. Prev Med. 1987;16:235-51.

11. Yusuf S, Hawken S, Ounpuu S, Bautista L, Franzosi MG, Commerford P, Lang CC, Rumboldt Z, Onen CL, Lisheng L, INTERHEART Study Investigators, et al. Obesity and the risk of myocardial infarction in 27,000 participants from 52 countries: a case-control study. Lancet. 2005;366:1640-9.

12. Fujimoto WY, Bergstrom RW, Boyko EJ, Chen KW, Leonetti DL, NewellMorris L, Shofer JB, Wahl PW. Visceral adiposity and incident coronary heart disease in Japanese-American men. The 10-year follow-up results of the Seattle Japanese-American Community Diabetes Study. Diabetes Care. 1999;22:1808-12.

13. Britton KA, Massaro JM, Murabito JM, Kreger BE, Hoffmann U, Fox CS. Body fat distribution, incident cardiovascular disease, cancer, and allcause mortality. J Am Coll Cardiol. 2013;62:921-5.

14. Kanai H, Matsuzawa Y, Kotani K, Keno Y, Kobatake T, Nagai Y, Fujioka S, Tokunaga K, Tarui S. Close correlation of intra-abdominal fat accumulation to hypertension in obese women. Hypertension. 1990;16:484-90.

15. Thomas G, Sehgal AR, Kashyap SR, Srinivas TR, Kirwan JP, Navaneethan SD. Metabolic syndrome and kidney disease: a systematic review and metaanalysis. Clin J Am Soc Nephrol. 2011;6:2364-73.

16. Hanai K, Babazono T, Nyumura I, Toya K, Ohta M, Bouchi R, Suzuki K, Inoue A, Iwamoto Y. Involvement of visceral fat in the pathogenesis of albuminuria in patients with type 2 diabetes with early stage of nephropathy. Clin Exp Nephrol. 2010;14:132-6.

17. Goldbourt U, Holtzman E, Cohen-Mandelzweig L, Neufeld HN. Enhanced risk of coronary heart disease mortality in lean hypertensive men. Hypertension. 1987;10:22-8.

18. Stamler R, Ford CE, Stamler J. Why do lean hypertensives have higher mortality rates than other hypertensives? Findings of the hypertension detection and follow-up program. Hypertension. 1991;17:553-64.

19. Colangelo LA, Vu TH, Szklo M, Burke GL, Sibley C, Liu K. Is the association of hypertension with cardiovascular events stronger among the lean and normal weight than among the overweight and obese? The multi-ethnic study of atherosclerosis. Hypertension. 2015;66:286-93.

20. Weber MA, Neutel JM, Smith DH. Contrasting clinical properties and exercise responses in obese and lean hypertensive patients. J Am Coll Caridiol. 2001;37:169-74.

21. Bouchi R, Minami I, Ohara N, Nakano Y, Nishitani R, Murakami M, Takeuchi T, Akihisa M, Fukuda T, Fujita M, et al. Impact of increased visceral adiposity with normal weight on the progression of arterial stiffness in Japanese patients with type 2 diabetes. BMJ Open Diabetes Res Care. 2015;3:e000081.

22. DeMarco VG, Aroor AR, Sowers JR. The pathophysiology of hypertension in patients with obesity. Nat Rev Endocrinol. 2014;10:364-76.

23. Putnam K, Shoemaker R, Yiannikouris F, Cassis LA. The renin-angiotensin system: a target of and contributor to dyslipidemias, altered glucose homeostasis, and hypertension of the metabolic syndrome. Am J Physiol Hear Circ Physiol. 2012;302:H1219-30.

24. Hall JE, Granger JP, do Carmo JM, da Silva AA, Dubinion J, George E, Hamza S, Speed J, Hall ME. Hypertension: physiology and pathophysiology. Compr Physiol. 2012;2:2393-442.

25. Schena FP, Gesualdo L. Pathogenetic mechanisms of diabetic nephropathy. J Am Soc Nephrol. 2005;16(Suppl 1):S30-3.
26. Committee of the Japan Diabetes Society on the Diagnostic Criteria of Diabetes Mellitus. Report of the committee on the classification and diagnostic criteria of diabetes mellitus. J Diabetes Investig. 2010;1:212-28.

27. Matsuo S, Imai E, Horio M, Yasuda Y, Tomita K, Nitta K, Yamagata K, Tomino Y, Yokoyama H, Hishida A, Collaborators developing the Japanese equation for estimated GFR. Revised equations for estimated GFR from serum creatinine in Japan. Am J Kidney Dis. 2009;53:982-92.

28. Suzuki E, Kashiwagi A, Nishio Y, Egawa K, Shimizu S, Maegawa H, Haneda M, Yasuda H, Morikawa S, Inubushi T, et al. Increased arterial wall stiffness limits flow volume in the lower extremities in type 2 diabetic patients. Diabetes Care. 2001;24:2107-14.

29. Yamashina A, Tomiyama H, Takeda K, Tsuda H, Arai T, Hirose K, Koji Y, Hori S, Yamamoto Y. Validity, reproducibility, and clinical significance of noninvasive brachial-ankle pulse wave velocity as measures of arterial stiffness. Hypertens Res. 2002;25:359-64.

30. Katakami N, Osonoi T, Takahara M, Saitou M, Matsuoka TA, Yamasaki Y, Shimomura I. Clinical utility of brachial-ankle pulse wave velocity in the prediction of cardiovascular events in diabetic patients. Cardiovasc Diabetol. 2014;13:128

31. Bouchi R, Babazono T, Yoshida N, Nyumura I, Toya K, Hayashi T, Hanai K, Tanaka N, Ishii A, Iwamoto Y. Association of albuminuria and reduced estimated glomerular filtration rate with incident stroke and coronary artery disease in patients with type 2 diabetes. Hypertens Res. 2010;33:1298-304.

32. Anavekar NS, Gans DJ, Berl T, Rohde RD, Cooper W, Bhaumik A, Hunsicker LG, Rouleau JL, Lewis JB, Rosendorff C, et al. Predictors of cardiovascular events in patients with type 2 diabetic nephropathy and hypertension: a case for albuminuria. Kidney Int. 2004;92:S50-5.

33. Dinneen SF, Gerstein HC. The association of microalbuminuria and mortality in non-insulin-dependent diabetes mellitus. A systematic overview of the literature. Arch Intern Med. 1997;157:1413-8.

34. Mansour AS, Yannoutsos A, Majahalme N, Agnoletti D, Safar ME, Ouerdane S, Blacher J. Aortic stiffness and cardiovascular risk in type 2 diabetes. J Hypertens. 2013;31:1584-92.

35. Cardoso CR, Ferreira MT, Leite NC, Salles GF. Prognostic impact of aortic stiffness in high-risk type 2 diabetic patients: the Rio de Janeiro Type 2 Diabetes Cohort Study. Diabetes Care. 2013;36:3772-8.

36. Bouchi R, Babazono T, Mugishima M, Yoshida N, Nyumura I, Toya K, Hanai K, Tanaka N, Ishii A, Uchigata Y, et al. Arterial stiffness is associated with incident albuminuria and decreased glomerular filtration rate in type 2 diabetic patients. Diabetes Care. 2011;34:2570-5.

37. Chandra A, Neeland IJ, Berry JD, Ayers CR, Rohatgi A, Das SR, Khera A, McGuire DK, de Lemos JA, Turer AT. The relationship of body mass and fat distribution with incident hypertension: observations from the Dallas Heart Study. J Am Coll Cardiol. 2014;64:997-1002.

38. Hayashi T, Boyko EJ, Leonetti DL, McNeely MJ, Newell-Morris L, Kahn SE, Fujimoto WY. Visceral adiposity is an independent predictor of incident hypertension in Japanese Americans. Ann Intern Med. 2004;140:992-1000.

39. Anderson PJ, Chan JC, Chan YL, Tomlinson B, Young RP, Lee ZS, Lee KK, Metreweli C, Cockram CS, Critchley JA. Diabetes Care. 1997;20:1854-8.

40. Foster MC, Hwang SJ, Massaro JM, Hoffmann U, DeBoer IH, Robins SJ, Vasan RS, Fox CS. Association of subcutaneous and visceral adiposity with albuminuria: the Framingham Heart Study. Obesity (Silver Spring). 2011;19:1284-9.

41. Bouchi R, Takeuchi T, Akihisa M, Ohara N, Nakano Y, Nishitani R, Murakami M, Fukuda T, Fujita M, Minami I, et al. High visceral fat with low subcutaneous fat accumulation as a determinant of atherosclerosis in patients with type 2 diabetes. Cardiovasc Diabetol. 2015;14:136.

42. Jung CH, Kim BY, Kim KJ, Jung SH, Kim CH, Kang SK, Mok JO. Contribution of subcutaneous abdominal fat on ultrasonography to carotid atherosclerosis in patients with type 2 diabetes mellitus. Cardiovasc Diabetol. 2014;13:67.

43. Kim G, Jo K, Kim KJ, Lee YH, Han E, Yoon HJ, Wang HJ, Kang ES, Yun M. Visceral adiposity is associated with altered myocardial glucose uptake measured by (18)FDG-PET in 346 subjects with normal glucose tolerance, prediabetes, and type 2 diabetes. Cardiovasc Diabetol. 2015;14:148.

44. Davy KP, Hall JE. Obesity and hypertension: two epidemics or one? Am J Physiol Regul Integr Comp Physiol. 2004;286:R803-13. 
45. Rumantir MS, Vaz M, Jennings GL, Collier G, Kaye DM, Seals DR, Wiesner GH. Brunner-La Rocca HP, Esler MD. Neural mechanisms in human obesity-related hypertension. J Hypertens. 1999;17:1125-33.

46. Mørkedal B, Romundstad PR, Vatten LJ. Mortality from ischaemic heart disease: age-specific effects of blood pressure stratified by body-mass index: the HUNT cohort study in Norway. J Epidemiol Community Health. 2011;65:814-9.

47. Hall JE, do Carmo JM, da Silva AA, Wang Z, Hall ME. Obesity-induced hypertension: interaction of neurohumoral and renal mechanisms. Circ Res. 2015;13(116):991-1006.

48. Chrysant SG, Chrysant GS. New insights into the true nature of the obesity paradox and the lower cardiovascular risk. J Am Soc Hyperntes. 2013;7:85-94.
49. Auclair A, Martin J, Bastien M, Bonneville N, Biertho L, Marceau S, Hould FS, Biron S, Lebel S, Lescelleur O, et al. Is there a role for visceral adiposity in inducing type 2 diabetes remission in severely obese Patients following biliopancreatic diversion with duodenal switch surgery? Obes Surg. 2015 (in press).

50. Goodwin K, Abrahamowicz M, Leonard G, Perron M, Richer L, Veillette S, Gaudet D, Paus T, Pausova Z. Dietary vitamin A and visceral adiposity: a modulating role of the retinol-binding protein 4 gene. J Nutrigenet Nutrigenomics. 2015;8:164-73.

\section{Submit your next manuscript to BioMed Central and we will help you at every step:}

- We accept pre-submission inquiries

- Our selector tool helps you to find the most relevant journal

- We provide round the clock customer support

- Convenient online submission

- Thorough peer review

- Inclusion in PubMed and all major indexing services

- Maximum visibility for your research

Submit your manuscript at www.biomedcentral.com/submit
() Biomed Central 